\title{
Salt mineralogy and stratigraphy of the Cretaceous evaporites of the West African margin
}

PiChat AlEXANDRE ${ }^{1}$, GindRE-CHANU LAURENT ${ }^{2}$ DELhaYe-PRAT VINCENT ${ }^{3}$, GAUCHER ERIC C. ${ }^{3}$, FERRAGe ERIC ${ }^{4}$, PEDLEY ANDREW ${ }^{5}$

${ }^{1}$ E2S-UPPA, IPRA, Univ. Pau \& Pays Adour; 64013, Pau, France (alexandre.pichat@gmail.com)

2 TERRA GEOSCIENCES (laurent.gindre17@gmail.com)

${ }^{3}$ TOTAL, CSTJF, avenue Larribau, 64000 Pau, France

${ }^{4}$ IC2MP UMR 7285 - Université de Poitiers, Poitiers, France (eric.ferrage@univ-poitiers.fr)

${ }^{5}$ Minsearch Geological Consulting (andrew@minsearch.co.za)

The Aptian evaporites of the South Atlantic precipitated in a former salt giant basin extending over thousand kilometres between Africa and Brazil during the opening of the Central Altantic Ocean. The geological setting of these evaporites are still poorly understood. We investigated cores and well log data in the proximal domain of the Congo-Gabon(Cabinda area to further constrain the sedimentology and stratigraphy of the evaporites. The salt section displays eleven sulphatefree evaporitic cycles limited by few meter-thick organic-rich shales. Each cycles starts with a crystalline halite grading upward to nodular carnallite and fine-grained halite interbeds. The sequences end by a fine-grained carnallite and localized caps of bischofite-tachyhydrite. The shales and meter-thick halite - carnallite beds can be correlated over 400 $\mathrm{km}$ from the South Gabon to the Cabinda, suggesting their precipitation from an extended single brine body. Conversely, the bischofite-tachyhydrite deposits can be up to 60 metersthick and are localized in depocenters probably related to ransform fault activity. This spatial distribution of the ultimate salts suggests an active tectonic setting during salt deposition. The evaporite section ends with gypsiferous deposits marking the progressive drowning of the basin by marine water. Finally, detailed analyses of the different evaporites textures enable to propose an evolution of the bathymetric conditions during salt deposition. 